THE TOLLS OF UNCERTAINTY 



\title{
The Tolls of Uncertainty
}

\author{
HOW PRIVILEGE AND THE
}

GUILT GAP SHAPE UNEMPLOYMENT

IN A MERICA

SARAH DAMASKE 


\section{Copyright (C) 2021 by Princeton University Press}

Princeton University Press is committed to the protection of copyright and the intellectual property our authors entrust to us. Copyright promotes the progress and integrity of knowledge. Thank you for supporting free speech and the global exchange of ideas by purchasing an authorized edition of this book. If you wish to reproduce or distribute any part of it in any form, please obtain permission.

Requests for permission to reproduce material from this work should be sent to permissions@press.princeton.edu

Published by Princeton University Press 41 William Street, Princeton, New Jersey o8540 6 Oxford Street, Woodstock, Oxfordshire OX20 1TR press.princeton.edu

All Rights Reserved

Library of Congress Cataloging-in-Publication Data

Names: Damaske, Sarah, author.

Title: The tolls of uncertainty : how privilege and the guilt gap shape unemployment in America / Sarah Damaske.

Description: Princeton : Princeton University Press, [2021] | Includes bibliographical references and index.

Identifiers: LCCN 2020046926 (print) | LCCN 2020046927 (ebook) | ISBN 9780691200149 (hardback) | ISBN 9780691219318 (e-book)

Subjects: LCSH: Unemployment-United States. | Discrimination in employment-United States. | Unemployed-Mental health-United States.

Classification: LCC HD5724 .D323 2021 (print) | LCC HD5724 (ebook) | $\mathrm{DDC}_{331.13 / 70973-\mathrm{dc} 23}$

LC record available at https://lccn.loc.gov/2020046926

LC ebook record available at https://lccn.loc.gov/2020046927

British Library Cataloging-in-Publication Data is available

Editorial: Meagan Levinson, Jacqueline Delaney

Production Editorial: Elizabeth Byrd

Jacket Design: Karl Spurzem

Production: Erin Suydam

Publicity: Maria Whelan, Kathryn Stevens

Jacket image by Aleksandr Davydov / Alamy Stock Photo

This book has been composed in Arno

Printed on acid-free paper. $\infty$

Printed in the United States of America

$\begin{array}{llllllllll}10 & 9 & 8 & 7 & 6 & 5 & 4 & 3 & 2 & 1\end{array}$ 
For Stephen Knapp, who taught me “The Definition of Possible," and

to Paul Damaske, who still makes me mix tapes 
